\title{
RET Mutation/Fusion Inhibitor BLU-667
}

National Cancer Institute

\section{Source}

National Cancer Institute. RET Mutation/Fusion Inhibitor BLU-667. NCI Thesaurus. Code C132295.

An orally bioavailable selective inhibitor of mutant forms of and fusion products involving the proto-oncogene receptor tyrosine kinase RET, with potential antineoplastic activity. Upon administration, BLU-667 binds to and targets various RET mutants and RET containing fusion product. RET gene mutations and translocations result in the upregulation and/or activation of RET tyrosine kinase activity in various cancer cell types; dysregulation of RET activity plays a key role in the development and regression of these cancers. 